\title{
The Gentle Giant: Kenneth Daniel Blackfan and his contributions to pediatric neurosurgery
}

\author{
Yasser Jeelani • Alan R. Cohen
}

Received: 5 February 2015 / Accepted: 12 February 2015 / Published online: 27 February 2015

(C) Springer-Verlag Berlin Heidelberg 2015

\begin{abstract}
"You must remember that I am not a successful neurological surgeon, only a professor, and that makes a great difference in the car that one drives."

Kenneth Blackfan to Walter Dandy, in a letter dated November 5, 1925
\end{abstract}

\section{Introduction}

Kenneth Daniel Blackfan's medical career spanned several disciplines. After initially working as a bacteriologist in Albany immediately after graduating medical school, he joined his father in general practice in New York. Blackfan subsequently underwent pediatric residency training at three different hospitals: (1) The St. Vincent's Foundling Hospital in Philadelphia, (2) Washington University in St. Louis, and (3) Johns Hopkins Hospital. He subsequently was appointed Chairman of the Department of Pediatrics at the University of Cincinnati from where he moved on to become Chairman of the Department of Pediatrics at Boston Children's Hospital and Thomas Morgan Rotch Professor of Pediatrics at Harvard Medical School.

A common theme throughout Blackfan's career was his acumen for scientific research and its application to the practice of pediatrics. From his work on the clinical detection of thrombosis of the cerebral venous sinuses to his legendary experiments on CSF flow, Blackfan's contributions to neurosurgery came at a time when neurosurgery was evolving into a specialty in itself. Also notable are his personal friendships

Y. Jeelani $\cdot$ A. R. Cohen $(\bowtie)$

Department of Neurosurgery, Boston Children's Hospital, Harvard

Medical School, 300 Longwood Ave, Boston, MA 02115, USA

e-mail: alan.cohen@childrens.harvard.edu with Walter Dandy and Harvey Cushing, the two leading neurosurgeons of his era.

\section{Early life and education}

Kenneth Blackfan was born in Cambridge, New York, on September 9, 1883. His father, Henry S. Blackfan, and grandfather were renowned physicians who had established a general practice there. Blackfan began his medical training at age 17 at the Albany Medical School of Union University (Fig. 1). In 1905, at age 22, he had graduated first in his class [1]. As a medical student, he was greatly influenced by Dr. Richard M. Pearce, Professor of Pathology and Bacteriology. Blackfan was particularly impressed by Pearce's attention to the scientific aspects of medicine. Immediately after graduation, he joined the Bender Laboratory at Albany Hospital as Pathologist and Assistant Bacteriologist under Pearce's supervision. Blackfan's inclination towards lab-based research was thus evident at a very early stage of his career.

In 1907, following a year-long stint in the Bender laboratory, Blackfan moved back to Cambridge, New York, to join his father in general practice as a country doctor. Fondly known as "young Doctor Ken," he would later recount to others the delights of "driving around the country-side on the varied errands of a general practitioner" [2], typically on a horse and buggy. He spent 3 years in this setting.

In 1910, Blackfan returned to Albany to work with Dr. Harry Shaw, the Clinical Professor on Diseases of Children at Albany Medical College, after becoming discontent with the practice of medicine in a rural setting. That same year, inclined towards a career in pediatrics, he decided to leave Albany to work under Dr. Samuel Hamill and Dr. David Edsall at the Polioclinic Hospital in Philadelphia (Edsall later 


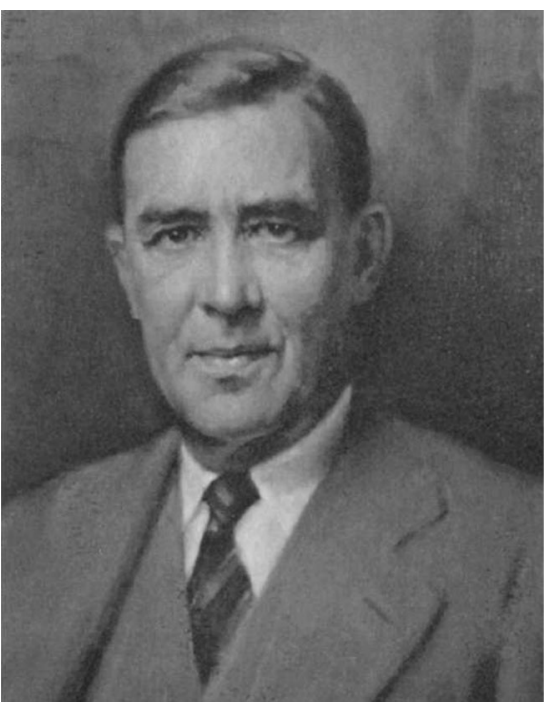

Fig. 1 Kenneth Daniel Blackfan, oil on canvas (portrait by Alexander James, c. 1920)

went on to become Dean of Harvard Medical School). A few months after joining, Blackfan was given the opportunity to become a resident at St. Vincent's Foundling Hospital in Philadelphia, an orphanage that at the time housed a hundred children. Despite an extremely high infant mortality rate of above $90 \%$, St. Vincent's Hospital was a welcoming place for Blackfan's initial foray into pediatrics. Here, Blackfan acquired basic pediatric clinical skills and pursued research involved on the Calmette eye test and von Pirquet skin test. Both tests were used in the diagnosis of tuberculosis at the time. The von Pirquet test formed the basis of the Mantoux test, a test still utilized for the diagnosis of tuberculosis.

Two years later in 1912, Blackfan moved to St. Louis as an assistant in pediatrics at Washington University School of Medicine and resident at St. Louis Children's Hospital. He brought along his close friend and colleague, Borden Veeder, to help establish a pediatric service at Washington University. At the time, Washington University at St Louis was undergoing a reorganization partially funded by a grant from the Rockefeller foundation [3]. Here, he served under the tutelage of Dr. John Howland (Fig. 2).

Howland had been in St Louis for under a year when he was offered to succeed Professor Clemens Peter von Pirquet as professor in pediatrics at Johns Hopkins Hospital in Baltimore. von Pirquet was an Austrian pediatrician and scientist whose contributions include coining the term "allergy," as well as laying the basis for modern immunological science. The von Pirquet test was based on his findings of the role of immunity in tuberculosis-related disease. Notably, in 1909, von Pirquet declined proposals to take a position at the Pasteur Institute in Paris, accepting instead an invitation to become a professor at Johns Hopkins University. (Sadly, in 1928, Pirquet and his wife committed suicide together by ingesting potassium cyanide.)

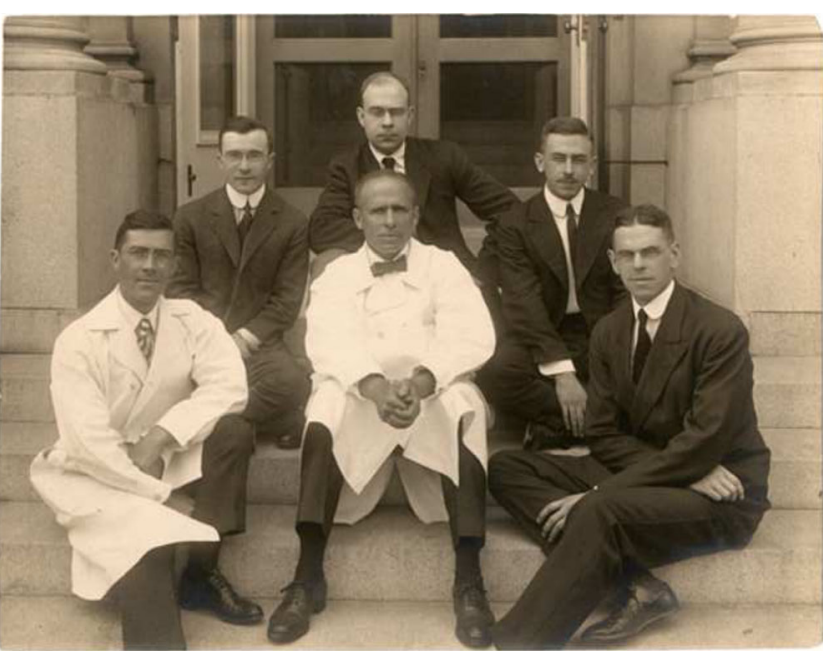

Fig. 2 John Howland (front row, center), seen with Kenneth Blackfan (front row, left) and Edwards Park (front row, right) on the steps of the Harriet Lane Home, Baltimore, MD

Howland offered to take Blackfan with him to Johns Hopkins, and they both moved to Baltimore in 1912. The decision to leave Washington University for Hopkins would prove decisive in Dr. Blackfan's academic career. His friend, Veeder, once remarked that perhaps his own greatest contribution to pediatrics was to stay back in St Louis and allow Blackfan to go to Baltimore with Howland [4].

\section{Baltimore years}

In 1912, Blackfan became a resident at the Harriet Lane Home and an instructor in pediatrics at Johns Hopkins Medical School. At the time, Hopkins had a newly built hospital with state-of-the-art laboratory facilities far beyond any other clinical department in the country. Nothing excited Blackfan more than the prospect of being able to participate in laboratory work in addition to his clinical responsibilities. The academic environment fostered by Howland eventually attracted a group of young, enthusiastic clinicians who were keen on utilizing this unique opportunity (Fig. 3). When Blackfan arrived in Baltimore however, the department of pediatrics at the Harriet Lane Home led by Prof. Howland consisted of Edwards "Ned" Park and three interns (Fig. 4). Park became head of the dispensary and Blackfan was in charge of the wards. The two remained close friends throughout their lifetimes. Park was also an important mentor of Charles Alderson Janeway, who is credited with defining the gamma globulin disorders that predispose children to infections and associated arthritic disorders. (Janeway went on to succeed Blackfan and became the Pediatrician-in-Chief at Boston Children's Hospital after Blackfan's death.) Personal correspondence between Park and Blackfan reveal a strong bond of friendship and profound mutual respect, after having worked together under 
Fig. 3 The pediatrics team at Harriet Lane Home, Baltimore, MD. Blackfan (second row, sitting, far right) is seen next to James Lawler Gamble (second row, sitting, second from right). Gamble later worked under Blackfan at Boston Children's Hospital

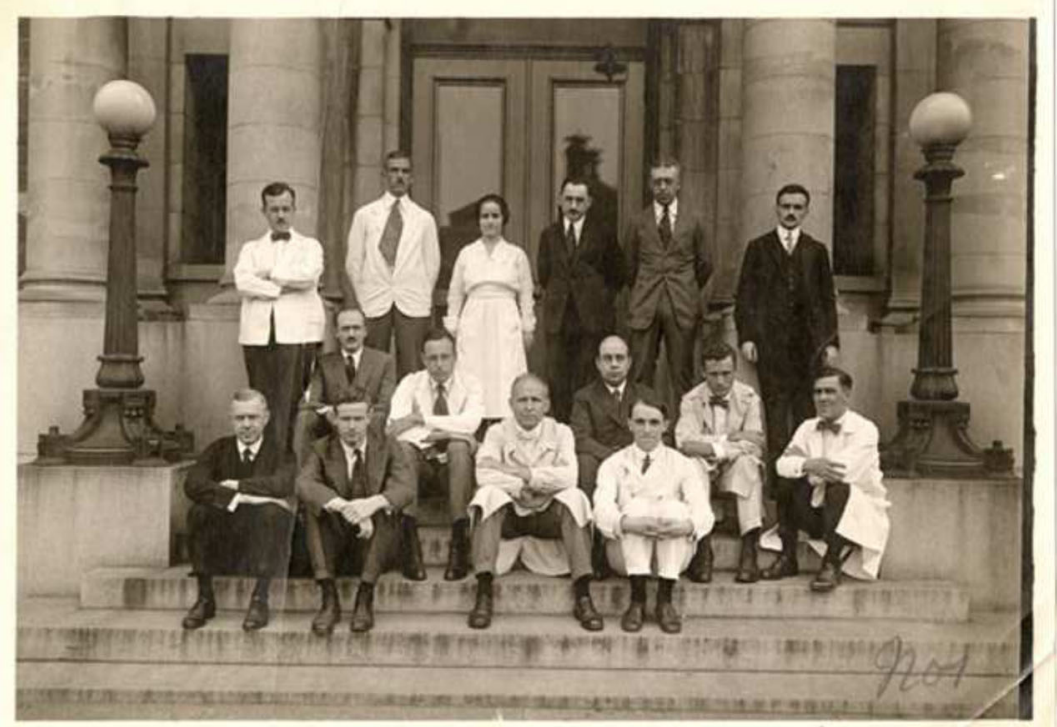

Howland's tutelage. In 1952, Park became the first recipient of the inaugural "John Howland Award," the highest honor bestowed by the American Pediatric Society.

When World War I broke out in 1914, The Johns Hopkins Medical Center mobilized to serve the nation both at home and abroad. The hospital's trustees approved the creation of an army hospital unit "Base Hospital No. 15," which was subsequently shifted to France. Blackfan was eager to serve abroad, but was excused owing to his trigeminal neuralgia (the military suspected that it would interfere with the discharge of his

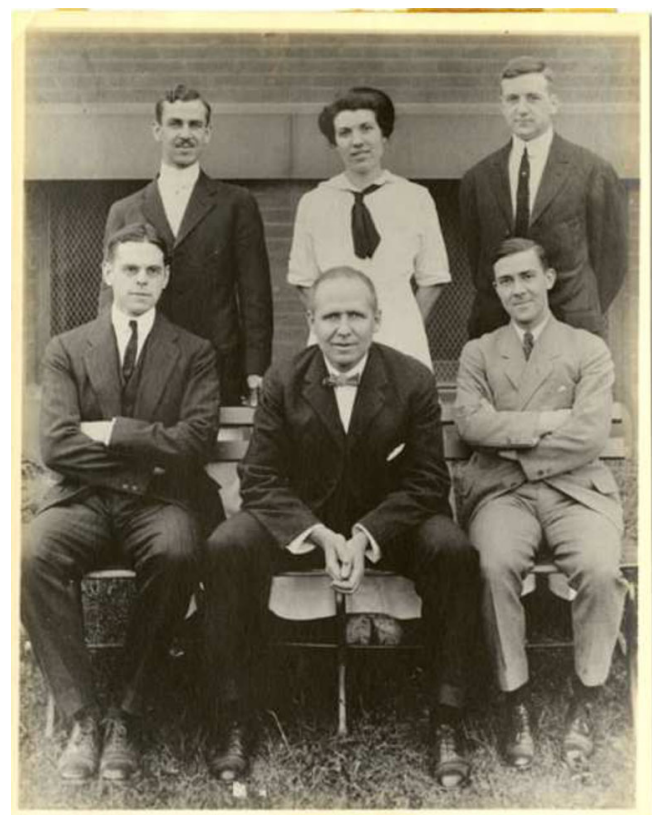

Fig. 4 The Department of Pediatrics at Harriet Lane home in 1912. Seen on either side of John Howland (center, sitting) are Edwards Park (front row, left) and Kenneth Blackfan (front row, right). While Blackfan was in charge of the wards, Park was the head of the dispensary duties). Howland did go, however, leaving Blackfan at the helm of affairs at The Harriet Lane Home. Blackfan thus continued as senior resident of pediatrics for 7 years, but was actually in charge at the Harriet Lane Home and taught pediatrics to many medical students. Upon Howland's return, Blackfan was immediately promoted to Associate Professor [3].

The 7 years Blackfan spent at Hopkins were some of the most productive of his career. In addition to standing out as a very able clinician, he was famed for his advocacy for patients - so closely allied that he would often refer to the subject as "we" [4]. His clinical experience was characterized by an exceedingly close social interaction and an emotional investment in his patients. Blackfan lived within the Harriet Lane Home itself. His living quarters consisted of a suite of rooms on the ground floor. Given his warm hospitable nature, this area turned into the "lounging place" for the entire staff. Though devoid of any privacy, Blackfan nevertheless enjoyed being the center of social life at Harriet Lane [2].

As excellent as he was as a clinician himself, Blackfan was always mindful of his interactions with his mentor, Prof. Howland. Edward Park, in his recollection of the history of the Harriet Lane, noted how Blackfan understood his mentor perfectly. When Blackfan presented a case to Howland, albeit in full knowledge of what the clinical diagnosis was, he "would present it in such a way that Howland would have the pleasure of making the diagnosis himself" [5]. Blackfan would thus pretend to not know the diagnosis much to the amusement of the intern staff. At the end of his 7-year residency at Harriet Lane, Blackfan was considered to be as good as his mentor, if not even abler [5]. Though Howland took pride in how diligent a student Blackfan was, he never thought of Blackfan as being "university material." Ironically, Howland is said to have strongly advised against hiring Blackfan as chair of pediatrics at Harvard [5]. 
Hopkins had more to offer than just clinical expertise. It was there that Blackfan met his friend and collaborator, the neurosurgeon Walter Edward Dandy. The circumstances that resulted in Dandy being at Hopkins at the time are part of neurosurgical folklore.

Dandy had transferred to Johns Hopkins Medical School in 1907 from the University of Missouri as a second year student. In his senior year, Dandy obtained consent from Harvey Cushing to perform research at the Hunterian Laboratory. Cushing himself had moved to Baltimore in 1896 as William Stewart Halsted's assistant resident in surgery. In Baltimore, Cushing was instrumental in the establishment of the Hunterian Laboratory, where experimental work on surgery and pathology was carried out on dogs. In 1910, Cushing appointed Dandy as an assistant surgeon in the Hunterian Laboratory following his graduation from Johns Hopkins Medical School. A year later in 1911, Dandy was inducted into the surgical service at Johns Hopkins Hospital as one of Cushing's assistant residents along with Howard C. Naffziger. (Naffziger went on to chair the Department of Neurosurgery at the University of California in San Francisco and also was nominated as the inaugural Chair of the Board of Directors of the American Board of Neurological Surgery.)

Cushing and Dandy developed a strained relationship throughout the time they were together at Hopkins, and their acrimonious feelings towards each other extended to the rest of their careers. Their first bone of contention arose in the results of an experiment that Dandy had performed at the Hunterian on the production of glycosuria in rabbits as a result of sympathetic stimulation. Subsequently, a second altercation occurred when Cushing visited the Hunterian to inquire on the progress of a CSF-related research project that Dandy and Blackfan had been working on for the past year. Cushing is said to have placed all the results and relevant materials in a box before Dandy removed them, claiming the research was his and that Cushing had no right to take them. Shortly thereafter, just prior to his departure for Harvard after accepting an offer to head the Department of Surgery at Peter Bent Brigham Hospital, Cushing informed Dandy that he would not be taking him along to Boston. To complicate things further for Dandy, Halstead was out of town on a summer vacation, leaving him with no job and his career in limbo [6].

Winford Smith, the hospital's superintendent at Hopkins at the time, arranged for Dandy to have a room in the hospital to allow for the continuation of Dandy's research while he waited for Halstead to return and determine his fate. During this time, Dandy continued working full time with Blackfan, who was also keen to participate in laboratory research during his residency. A common interest in scientific research applicable to their fields had sparked their collaborative efforts in studying hydrocephalus.

Blackfan's research with Dandy involved an experimental model to produce hydrocephalus in dogs that helped establish the basis of our current understanding of cerebrospinal fluid physiology. This work was published in two classical papers in the American Journal of Diseases in Children, one in 1913 and the other in 1917: "Internal Hydrocephalus-An Experimental, Clinical and Pathological Study" (Fig. 5). The second
Fig. 5 Blackfan and Dandy's work on hydrocephalus resulted in the publication of two landmark papers on CSF circulation, in (a) 1913 and (b) 1917 a

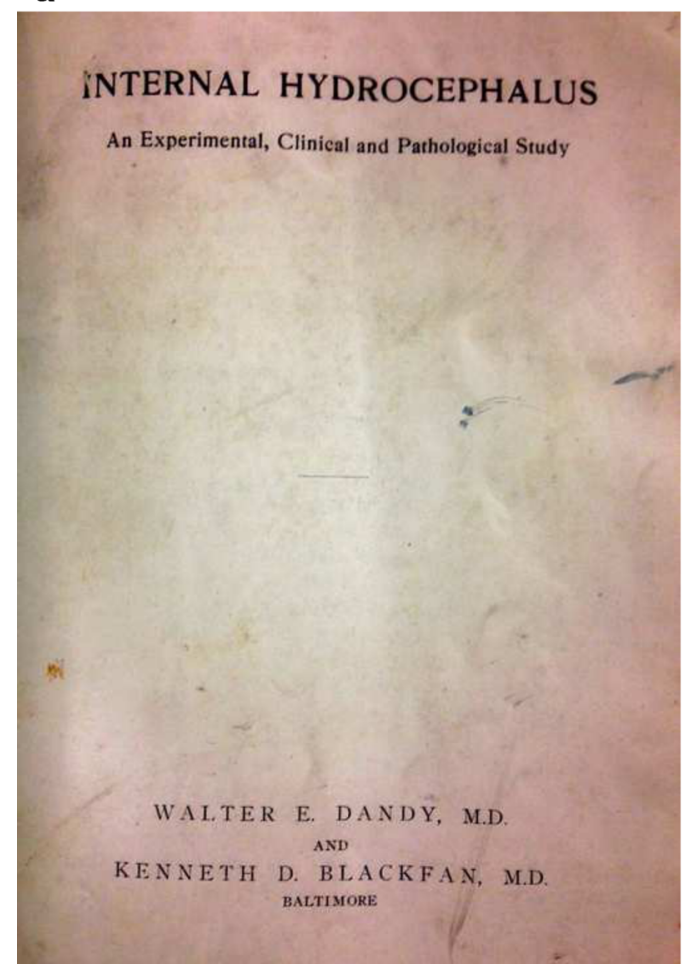

b

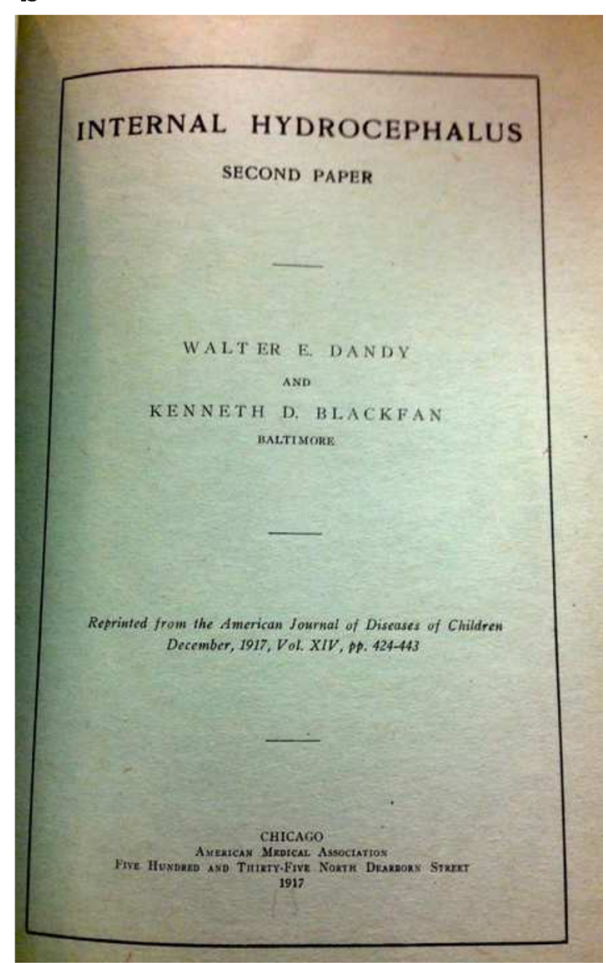


paper was later reprinted in the Annals of Surgery in 1919 [7]. Blackfan's collaborative work with Dandy also expanded to the description of internal hydrocephalus in infants, the early recognition of hydrocephalus in children, the signs of cerebral venous thrombosis, and a landmark paper on the treatment of meningococcal meningitis. The originality of this research prompted Halstead to find a place for Dandy as an assistant resident surgeon.

A unique facet of Blackfan's research was his ability to apply his laboratory investigations to his clinical experience in what would be called translational science today. Blackfan conducted classical studies in hematology, fluid replacement, and nutritional deficiencies in childhood. He also developed a novel method for the administration of salt solution through the peritoneal cavity for the treatment of dehydration. He realized that dehydration was much more dangerous than acidosis in diarrheal diseases and shifted the emphasis from alkali to fluid replacement for better management of the condition. This discovery laid the basis for fluid replacement in infant diarrheal diseases that is followed to this day.

Blackfan, however, did not have the luxury of pursuing his research interests at leisure. Howland's philosophy was that the sole duty of residents was to provide patient care; thus, Blackfan's engagement in research would have been frowned upon [2]. For fear of interfering with his clinical responsibilities, Blackfan pursued his laboratory research in a clandestine fashion, often working at night [2]. He was fortunate enough to have a partner in Dandy, who was equally enthusiastic for research at odd hours. In a letter dated March 24, 1930, when Blackfan was Chairman of Pediatrics at Harvard, Dandy recalls their hard work at night together:

"I am delighted to know how happy you are and how well everyone speaks of you, all of which is, of course, due to your carrying test tubes of phthalein with me in the wee hours of the morning many, many years ago".

\section{Cincinnati years}

In 1920, at age 37 and after 11 years of being a resident, Blackfan assumed his first academic appointment. During most of this time, he lived the life of a bachelor, surviving on a pittance of remuneration. One year after he was finally appointed associate professor at Hopkins, he accepted the B. K. Rachford Professorship of Pediatrics at the University of Cincinnati, along with the departmental chairmanship.

Blackfan had difficulty in establishing an independent department with full time staff in Cincinnati, given that pediatrics, as a separate specialty, was still in its relative infancy around the country. Through his organizational capability, he nevertheless strived to develop the department and oversaw addition of modern equipment along the lines of what was used at Hopkins. Just as at Hopkins, Blackfan commanded respect and affection from his junior colleagues and led by example.

Three years later, despite a large departmental bequest for the Department of Pediatrics at University of Cincinnati in the offing, Blackfan accepted a professorship at Harvard and moved to Boston [4]. Blackfan, by then, had laid the groundwork for his successor, Albert Graeme Mitchell, to further modernize the practice of pediatrics at Cincinnati. In 1928, 5 years after Blackfan left, Mitchell, through his friendship with William Cooper Procter (co-founder of Procter and Gamble, and member of the Board of Trustees for the Children's Hospital Cincinnati), was able to obtain a philanthropic endowment of \$2.5 million and thus lay the foundation for the Children's Hospital Research Foundation [8]. Children's Hospital Cincinnati thus became the first hospital in the country to have a building dedicated to research. Even today, the foundation remains the basis of one of the wealthiest pediatric research centers in the country [3].

\section{Boston years}

In 1923, Blackfan was appointed the Thomas Morgan Rotch Professor of Pediatrics at Harvard Medical School, Medical Director of the Infants' Hospital and Physician-in-Chief of Children's Hospital Boston. The Children's Hospital Boston was incorporated in 1869 at 9 Rutland Street with a capacity of 20 beds. It came to its current location on Longwood Avenue in 1914, alongside the new location for the Harvard Medical School, the "Great White Quadrangle" of which was erected 8 years earlier in 1906 [9].

Blackfan was the fourth chair of the department of medicine at the Children's Hospital Boston, succeeding Prof. Oscar Schloss. Schloss had been recruited from Cornell, after being invited by the Dean of Harvard Medical School, David Edsall, to join as the first full-time chairman. Previously, the department of pediatrics had a part-time chief in John Lovett Morse, an eminent pediatrician in Boston. As part of the agreement, Schloss was allowed to bring part of his team along with him, thus forcing out the many practitioners who worked part-time at Children's Hospital Boston. This resulted in great consternation for Morse, who retaliated by limiting patient referrals. The resulting financial strain forced Schloss to return to New York. It also inspired Edsall to recruit Blackfan [3]. When Blackfan took charge, he reappointed a number of the practitioners Schloss had forced to resign, thus re-establishing referral patterns that helped the Children's Hospital regain its reputation [3].

At Harvard, Blackfan enjoyed a steady rise to international renown. This stage of his career marked his transition from an excellent clinician to foremost pediatrician in the country. $\mathrm{He}$ was elected president of the American Pediatric Society in 
1938, after having served on its council from 1926 to 1933 . He was active as a member of the Association of American Physicians, the American Academy of Pediatrics, and the Society for Clinical Investigation. Internationally, he was a corresponding member of the British Pediatric Association and the Pediatric section of the Royal Society of Medicine of England. He also served on the Council of Pharmacy of the American Medical Association. In 1932, Blackfan was appointed delegate to the Berlin meeting of the International Committee on Nutrition sponsored by the League of Nations. Most notably, as Chairman of the Committee on Growth and Development of the Medical Section of the Third White House Conference held in 1931, he edited the four-volume report which, for a long time, was considered the standard text for graduate students in Pediatrics [1]. Blackfan also served as senior editor of the Journal of Pediatrics, upon its founding in 1932.

The national implications of the stellar success Blackfan enjoyed at the Children's Hospital Boston in establishing a center of excellence for pediatrics, especially one equipped with dedicated units for neurological care, are reflected in this euphoric letter from Edwards Park addressed to Blackfan on October 17, 1928:

"The letter, which I received calling my attention to the possibility that you might be given a neurological service filled me with great joy...we need a neurological service here terribly (at Johns Hopkins Medical Center)...What a wonderful thing it would be if you could consummate this thing in Boston. Would it not be greeted with tremendous enthusiasm the world over... would it not be copied everywhere! ... If you could obtain it in progressive Boston, perhaps we could attain it too in conservative Baltimore... Why won't some rich Bostonian take up the idea...Haven't you got a Mr. Procter in Boston?... who would hear the idea and supply the funds...Then after Mr. Procter had done it for you, you could send him to us. We would promise that our posterity used ivory soap for eternity."

While Blackfan's research was mainly focused on hydrocephalus during his time at Johns Hopkins, his research at Harvard shifted to hematological disorders. Fortuitously, Blackfan decided to mentor a young physician who would eventually be known as the "Father of Hematology," Louis K. Diamond. Diamond had first met Blackfan while attending one of his lectures on "How to examine an infant and a child." In a personal interview, he later remarked that Blackfan's lecture was so fascinating that he decided on a future in pediatrics immediately afterward [3].

After graduating from Harvard Medical School, Diamond approached Blackfan for a position at Children's Hospital Boston with an aim to pursue a career in pediatrics, but did not receive a consideration. To improve his credibility with Blackfan, Diamond worked with James Lawler Gamble and Charles F. McKhann on helping them with several research projects (Fig. 6). The latter two physicians were Blackfan's students who were trained by him at both Hopkins and Cincinnati, and had been recruited to Boston Children's Hospital by Blackfan himself. Diamond's hard work with McKhann was noticed by Blackfan, which eventually led him to offer Diamond a guaranteed trainee position on the condition that he instead join him first as a research fellow working to establish a hematology lab. Blackfan also promised to arrange the initial funding for the project. Diamond promptly accepted
Fig. 6 Department of Pediatrics at Children's Hospital Boston, c. 1931. Kenneth Blackfan (front row, sixth from left) is seen with Gamble (same row, fifth from left) and Charles F. McKhann (same row, fourth from left). Also seen in the picture are Louis K. Diamond (front row, two places to

Blackfan's left, in dark pants) and Captain LeRoy D. Fothergill (Head of Bacteriology Research). Fothergill was known for his work on Eastern Equine Encephalomyelitis

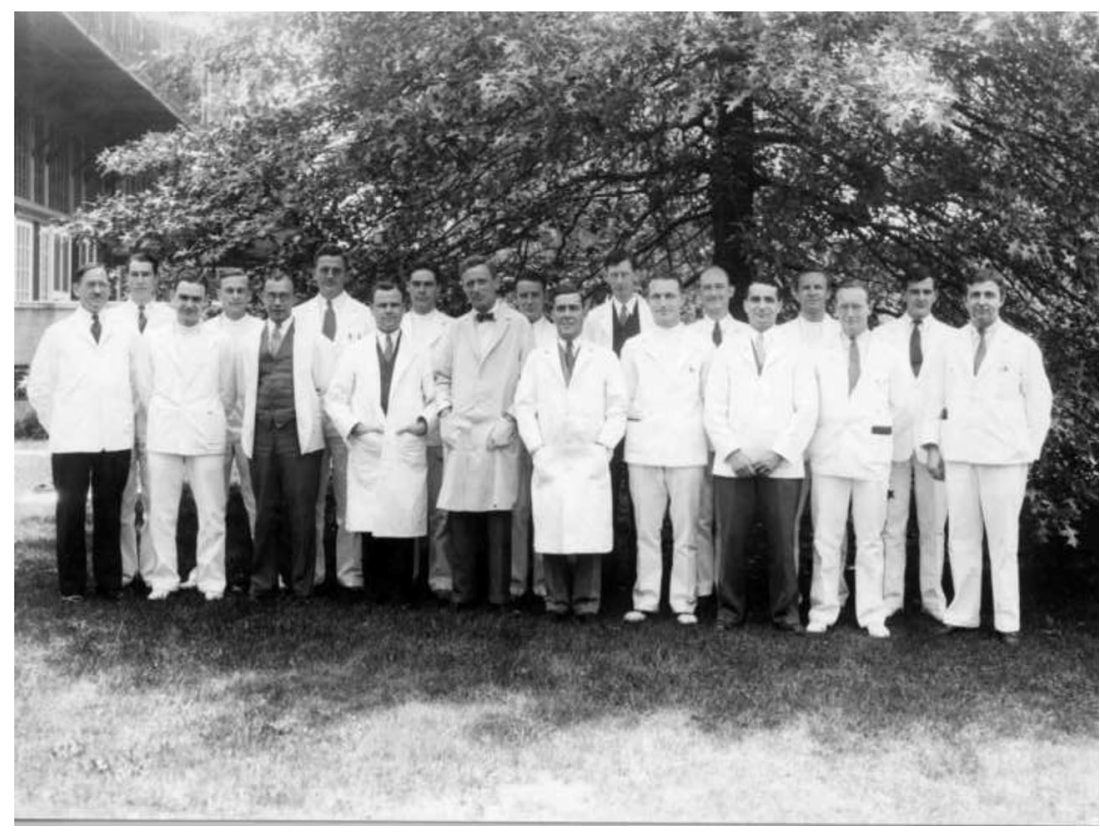




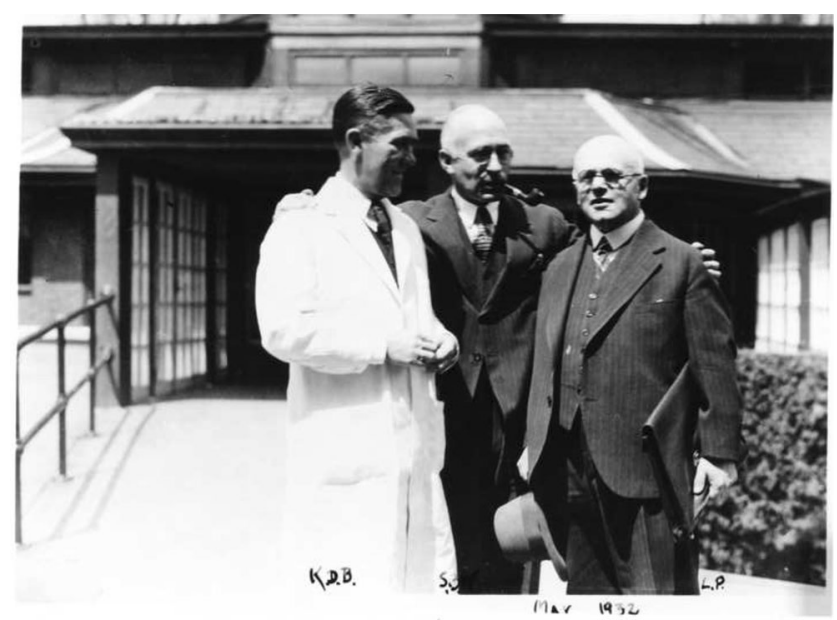

Fig. 7 Kenneth Blackfan (left), seen with Simeon B. Wolbach (center), Pathologist-in-Chief at Boston Children's Hospital from 1922 to 1947, and Ludwig Pick (right), Visiting Pathologist from Berlin, known for his work on pheochromocytoma, Niemann-Pick disease, Lubarsch-Pick disease, and Pick's cell. March 1932

and later realized that the promised fellowship funds were "barely enough to buy a single microscope and hire a lab technician." [3] Nonetheless, Diamond developed an interest in congenital blood-borne disorders and was introduced to Prof. Simeon Burt Wolbach, who was Pathologist-in-Chief at Children's Hospital at the time (Fig. 7). Blackfan's extensive work with Diamond culminated in the textbook Atlas of the Blood in Childhood by Blackfan and Diamond published in 1948, after Blackfan's death [10]. Together they described the thalassemias, erythroblastosis fetalis, and a hypoplastic variant of anemia named after them-Diamond-Blackfan anemia - among a host of other hematological disorders that hitherto were not yet described.

Blackfan also mentored Sidney Farber, who would eventually be known as the father of modern cancer chemotherapy.
Farber graduated from Harvard Medical School after having transferred there from the University of Heidelberg in Germany. He later trained in pathology at Peter Bent Brigham Hospital and subsequently was hired by Blackfan as a resident pathologist at Children's Hospital. In 1929, he became the first pathologist to be based at Children's Hospital and began his landmark research on leukemia, in collaboration with Blackfan and Diamond (Fig. 8). His work culminated in the discovery of folic acid antagonists that laid the basis for chemotherapy in cancer remission. Farber later established the Children's Cancer Research Foundation, which would fund a cancer clinic that Farber already started. One night, on May 22, 1958, a child being treated at the clinic appeared on a radio show. Farber introduced him as "Jimmy" to protect his identity. His story, heard on radio broadcast, ended up attracting a quarter million dollar donation, which were used to construct the Jimmy Fund Building alongside Children's Hospital. The Jimmy Fund Building was later renamed the Sidney Farber Cancer Institute, and is currently the Dana Farber Cancer Institute.

Blackfan's position at Boston Children's Hospital put him in close proximity to Harvey Cushing. Cushing was appointed Surgeon-in-Chief at the newly opened Peter Bent Brigham Hospital next door. Pediatric neurosurgery did not evolve as an independent sub-specialty until 1929 when the world's first pediatric neurosurgery unit was established at Boston Children's Hospital by Cushing's protégé Frank D. Ingraham [11]. Previously, children requiring neurosurgical intervention were treated by Cushing at the Brigham [12]. Blackfan thus developed a strong professional and personal bond with Cushing. Together, they discussed neurological presentations, pathologies, and outcomes. Cushing often sent requests for pathological examination of resected tumors to Blackfan and Diamond.
Fig. 8 Kenneth Blackfan (suit), with his students in this photograph, circa 1930. Charles McKhann (front row, second from right), Louis Diamond (front row, extreme left), and Sidney Farber (rear row, third from right) are also seen

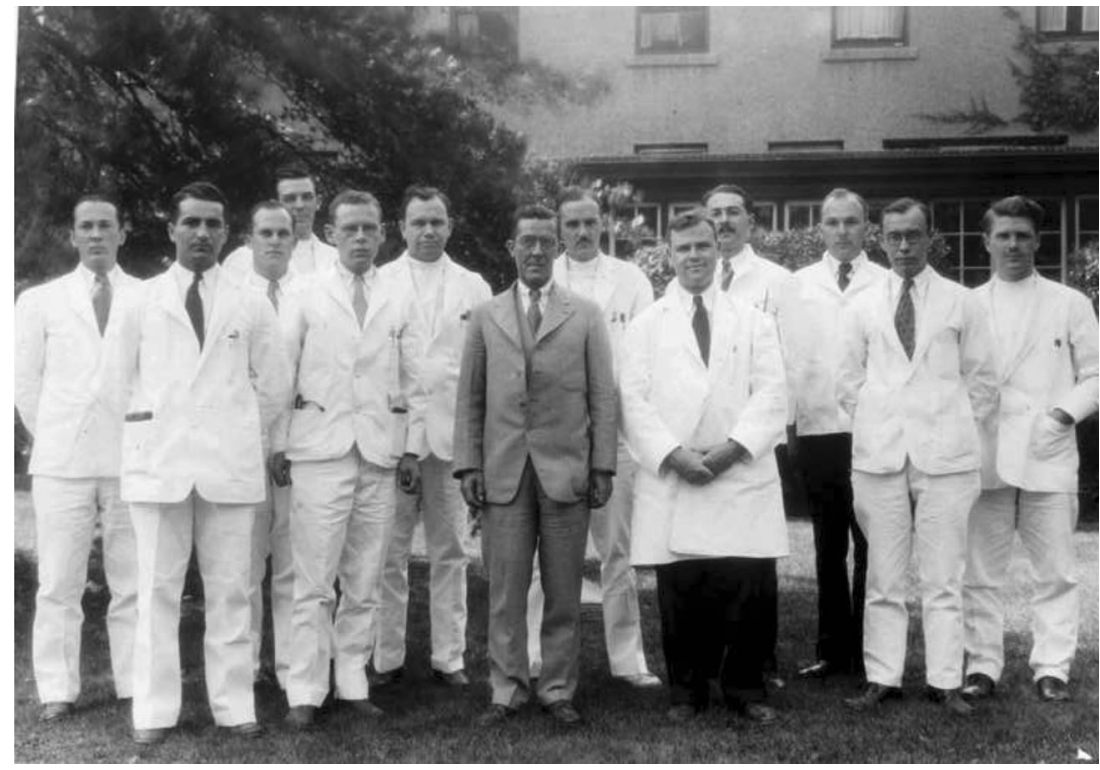




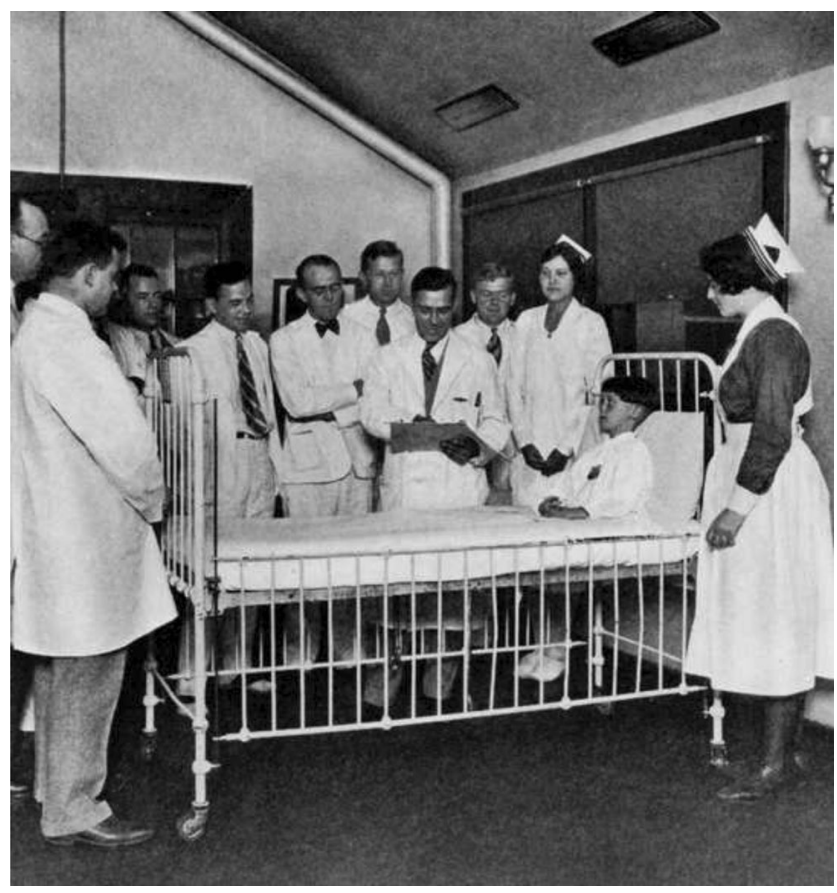

Fig. 9 Kenneth Blackfan (chart in hand) teaching at the bedside. Also seen standing at bedside are Charles McKhann (far left, hands crossed in front) and R. Cannon, junior resident (on Blackfan's immediate right, in bowtie), c. 1929

\section{Blackfan the teacher}

At five foot three inches tall, Blackfan was somewhat short and held the nickname "the Gentle Giant." Blackfan was a quiet and unassuming man whose demeanor was reserved and undemonstrative. His handling of the child was also calm, controlled, and reassuring. He emphasized the need to take the time to calm the child, while others would focus on methods of examination of a crying child.

A famed paradigm in Blackfan's philosophy was the notion that the medical student was the prime beneficiary of all teaching activities. According to his J. L. Wilson, his chief resident at Boston Children's, the order of his priorities were as follows: (a) the department, (b) the patient, (c) the student, and (d) the resident. His prioritizing medical students was often met with consternation by his residents who felt that they were unfairly treated. Blackfan felt that "a lazy or poor student reflected a poor instructor" [4]. He championed teaching at the bedside and in the clinic, and believed that the most effective way of learning was through responsible patient contact. Ward rounds with Blackfan were formal (Fig. 9). Every morning, Blackfan would decide on a patient he wished to focus his teaching around. His lofty standards of patient care often led him to be critical of residents, but his technique of reprimand never involved assigning direct blame, raising his voice or losing control (Fig. 10).

Leading by example, Blackfan believed that participation in research was indispensable for one to become a wellrounded physician. He did maintain, however, the physician must always place the well-being of each patient before everything else, including all aspects of teaching and research. Blackfan's paradigm of integrity of laboratory work and clinical medicine was adopted by Children's Hospital - the residency requirements entailed a year of research in the biochemical or bacteriological laboratories before assuming clinical responsibilities (Fig. 11).

Blackfan was not a skilled orator or writer. In fact, he would spend many hours putting sentences together while writing a paper or critically analyzing a manuscript — an experience many of the his subordinates would describe as "painful." Blackfan, however, was known to have a brilliant memory and could recall patient details most residents would trivially dismiss as casual (Fig. 12).

Blackfan's humanistic side has been widely commented upon by both his colleagues and those who he mentored. Edwards Park, in a memorial exercise on Blackfan, recounts how every morning at the entrance of Johns Hopkins Hospital, there used to be a self-appointed doorman named Ben. Ben was a old, yet cheerful, African American man whose appearance was remarkable for the presence of locomotor ataxia. He was known to have a strong interest in horse racing and boasted of being tipped in advance of what horses were most likely to win at the local derby. Blackfan would stop at the entrance daily, chat, and even bet a dollar or two based on Ben's recommendations just to witness the delight it would bring on his face. He would also send his barber, also a man of color, a postcard every time he would travel. Blackfan was an
Fig. 10 Kenneth Blackfan on rounds: "The Processional." A famous cartoon by Douglas A. Sunderland, MD shows Chief Resident James Wilson leading the procession followed by Blackfan, nurses, and housestaff

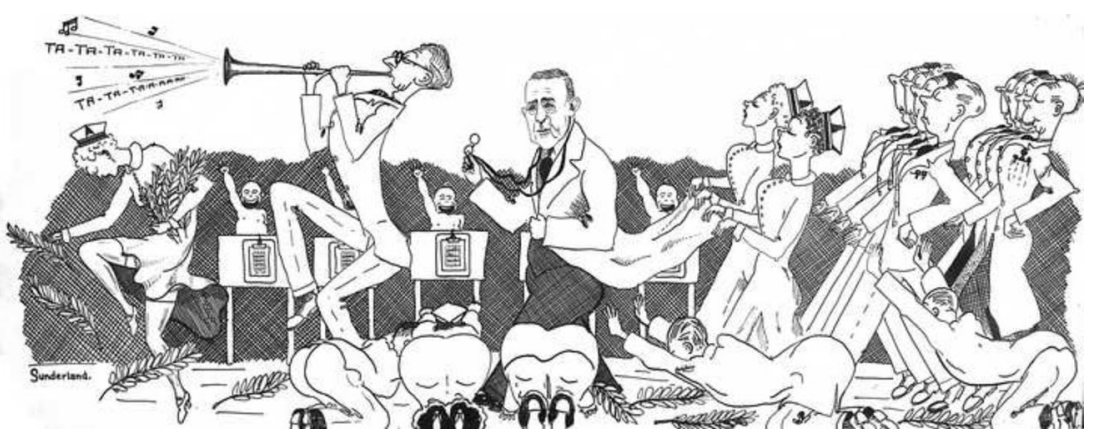




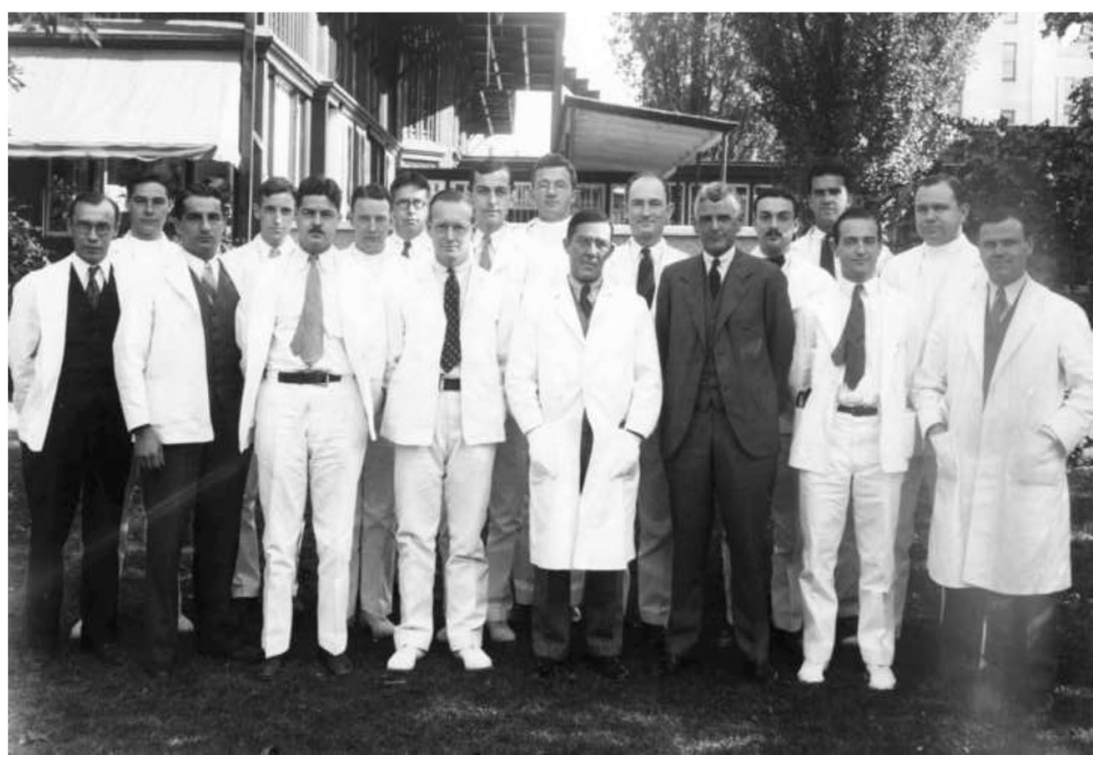

Fig. 11 Kenneth Blackfan, with his medical staff, 1931. Front row, from left to right: LeRoy Fothergill (Captain, US Navy and Head of Bacteriology Research), Louis K. Diamond (Chief Resident), Richard Nelson (Wichita Falls, TX), John Canaday (Glens Falls, NY), Kenneth Blackfan, Richard M. Smith (Pediatrician-in-Chief, 1942-1946), unknown, Charles F. McKhann (Associate Professor and Associate
Chief, Pediatrics). Standing in rear row, from left to right: Henry Pratt (New York), Alan Ross (Montreal), John E. Brown Jr. (Columbus, OH), Clement A. Smith, Fleek Miller (Newark, OH), John P. Hubbard (Former Head, National Board of Medical Examiners, Philadelphia, PA), Lucius E. Eckles (Topeka, KS), Lewis Koplick (Mount Sinai Hospital, NY), unknown, Lewis K. Sweet (Washington, DC) incredibly empathetic person and was mindful of all his interactions. As Park remarked, "in human relations, Blackfan never made a psychological error" [1].

\section{Blackfan the friend}

Personal correspondence between Blackfan and his friends reveal an affectionate and informal side that somewhat defied

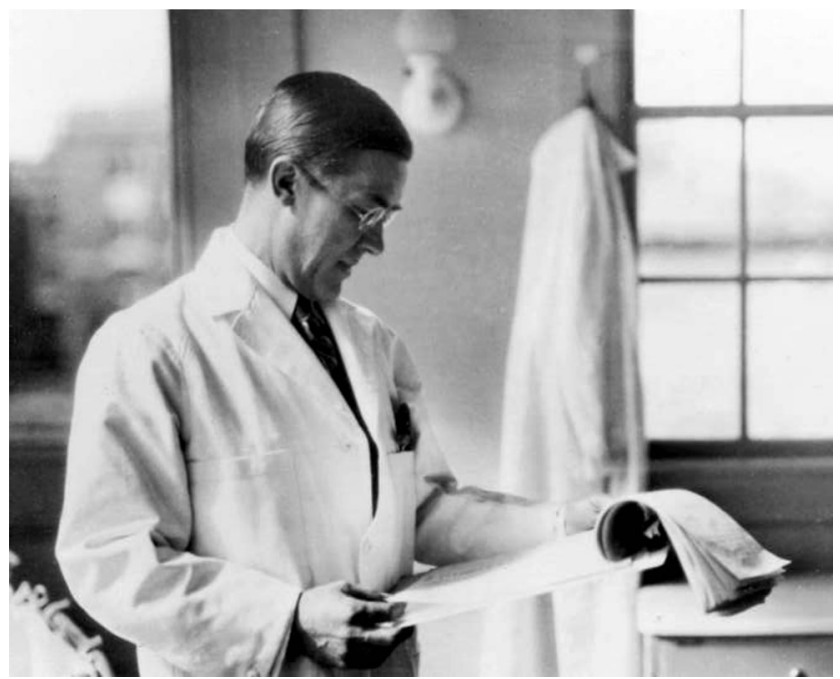

Fig. 12 Kenneth Blackfan, studying a patient chart at Boston Children's Hospital. (Cover illustration) his meticulously formal interaction in the hospital environment. Blackfan and Dandy kept writing to each other until long after he left Baltimore for Boston.

Blackfan would occasionally make references to Dandy's struggle in finding a wife:

"I hope you are home, \& did you bring a Parisian maiden with you?"

The two would also write on behalf of their apprentices, to seek career advice or to have them recruited. In a letter to Dandy, Blackfan wrote:

"I have a young fellow who is serving his internship in Pediatrics with me. This is part of a plan which he has made with the ultimate aim of becoming a neurosurgeon...I am writing to ask your opinion as to what should be his next step."

Dandy replied:

"My very strong advice to any young man wishing to do brain surgery is to get a thorough training in general surgery first. I know this is unorthodox advice...there would not be anything like the mortality in brain surgery in this country if the brain surgeons were properly trained."

While discussing their interest on CSF flow, Dandy and Blackfan often wrote to each other reminiscing on their experiments on dogs at the Hunterian. Blackfan, in a letter to Dandy wrote: 
"Although you tactfully refrained from drawing me in too fightfully, I am thoroughly in accord with your idea as to where the CSF goes, and am delighted at the conclusive proof you have. The article was needed."

Dandy replied: "I did have the impression that perhaps I was putting something over on you with the absorption of spinal fluid and I thought it was better not to incriminate you too much, but I am delighted to know that I was mistaken. I presume that it was simply the Boston atmosphere."

Blackfan and Dandy would also consult each other on other aspects of academic medicine including attaining publicity. On a newspaper cutting that had published an article on the amazing feat of pneumoencephalograms, pioneered by Dandy during the time he worked with Blackfan, the latter annotated the following:

"How do you pay for this sort of press agent stuff?"

(Fig. 13)

With Cushing, Blackfan appeared more formal in his interactions. "Blackie", as Cushing would affectionately call Blackfan, would write to Cushing on various subjects, especially bringing his attention to literature that would affect the management of their patients. They would also write to each other inquiring on common patients. In a letter dated May 20, 1929, Cushing wrote:

"I have just been out to Cleveland and returned to learn that you have gone over the top in your campaign. My

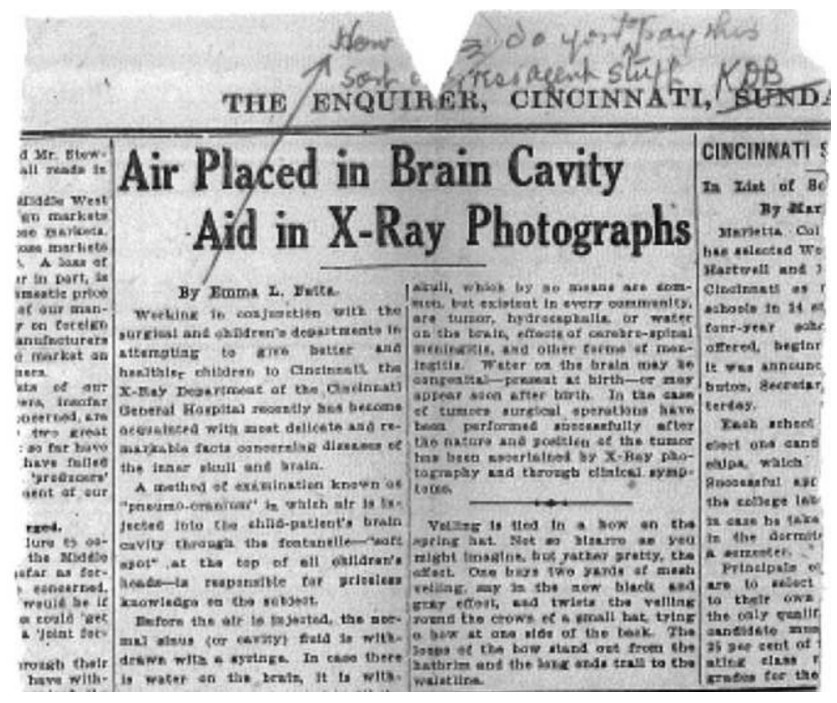

Fig. 13 A newspaper article in the The Enquirer, Cincinnati, comments on the newly invented technique of pneumoencephalography, developed at Hopkins by Walter Dandy. Seen above the headline is a hand-written note by Blackfan addressed to Dandy warm congratulations to you...I wonder how our little friend comes on, I saw her two or three weeks ago and things looked pretty unfavourable. I am sorry not to have dropped in on her more often, but the world is full of a number of things, etc."

Interestingly, Blackfan's correspondence also gives insights into the prevalent bias in recruiting young residents at the time. In reference to a candidate for a training position at Harvard, Park wrote to Blackfan:

"He is completely free from objectionable Jewish qualities but possesses the fineness of intellect characteristic of the race"

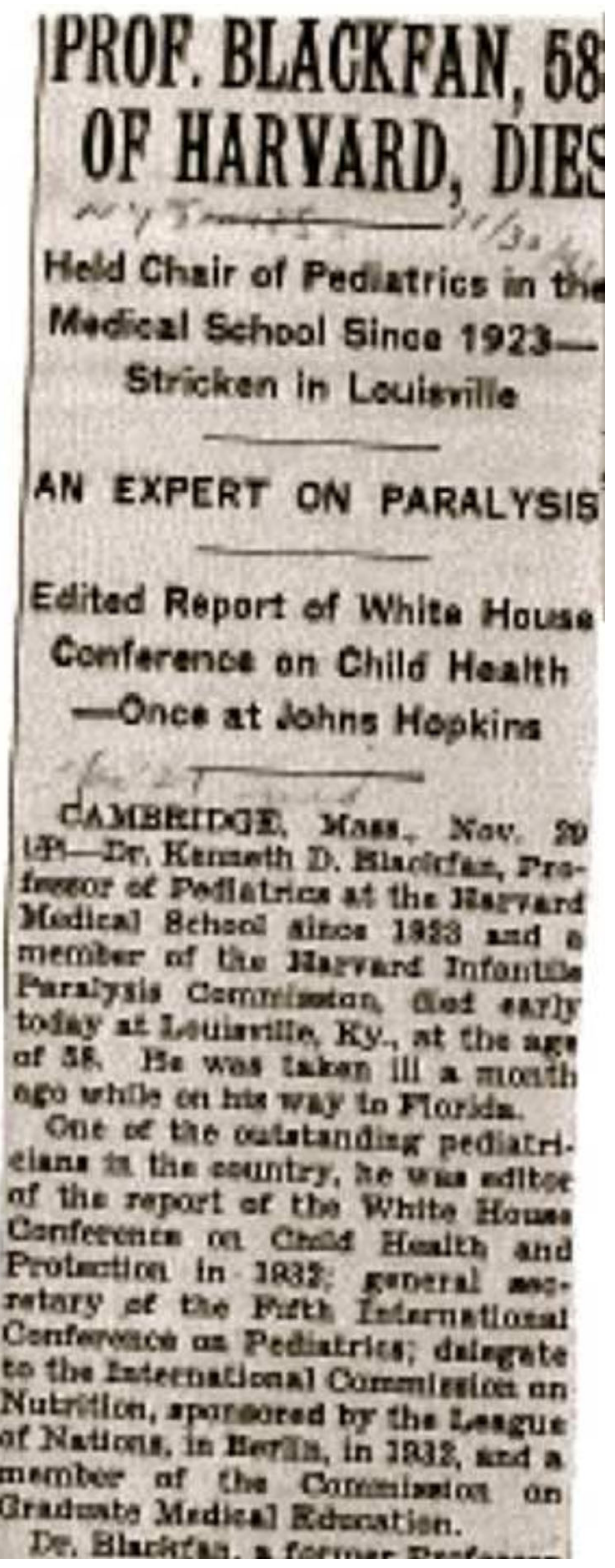

Fig. 14 Blackfan's obituary published in the New York Times, November 30, 1941 


\section{Personal life}

Blackfan married Lulie Anderson Bridges of Louisville, Kentucky, in 1920. He gained a stepson, Turner Bridges, from his wife's previous marriage. Despite having no children of his own, Blackfan was deeply invested in his stepson's future and upbringing. His home on Allerton Street in Brookline, Massachusetts, was "one of the greatest pleasures of his life" which he and his wife planned with great detail [1]. Mrs. Blackfan was known as a beautiful homemaker and hostess. The home was full of southern grace that the Blackfans had perfected. The family summered in Kentucky and Cambridge, New York. Blackfan used the long summer vacations in Cambridge to catch up on his reading and writing. In Cambridge, he personally supervised the construction of a lakeside holiday home with multiple guest cottages for his friends to come and spend time there, notably Dandy and Park:

"Is it too early to consider the possibility of you and Mrs. Dandy stopping off at the lake this summer or coming up to make us a visit? Lulie and I would love to have you," wrote Blackfan, in a letter to Dandy dated 1935.

Dandy, referring to their newly born daughter, wrote back saying, "I fear we will be fixed in Baltimore for there is a new lady at our house and she won't let us wander far".

\section{Final years}

Blackfan's adult life was marred by disabling tic douloureux throughout his tenure as Chairman at Boston Children's Hospital, though he seldom mentioned it to anyone. He was convinced by friend and associate, Walter Dandy, to undergo surgery to relieve his trigeminal neuralgia. This operation performed at Hopkins by Dandy himself resulted in severe complications of an anesthetic face, tongue, and eye on one side, resulting in significant disability, although he would rarely complain. Sadly, Blackfan's final years of his life were complicated by systemic neoplastic disease resulting from lung cancer. He was forced to take a sabbatical year in 1941 to relieve him from administrative and clinical duties due to his prolonged illness. Blackfan died at age 58, on November 29, 1941 in Louisville, Kentucky, one week before the attack on Pearl Harbor (Fig. 14).

As a testimony to how dedicated he was to pediatric research, practice, and teaching, he declined the offer to become Dean at Harvard Medical School, fearing that any additional administrative responsibilities would interfere with his love of pediatrics. He thus continued as Chairman of Pediatrics at
Boston Children's Hospital until his death. Sponsored by the Boston Children's Hospital Alumni Association since 1953, the nationally recognized Kenneth D. Blackfan Annual Lectureship features a world-renowned speaker on pediatric research, clinical care, and public health. It is held at Boston Children's Hospital and is attended by faculty from Harvard Medical School and Boston Children's Hospital, as well as by leading pediatricians, surgeons and biologists throughout the USA.

After Blackfan's death, the street upon which Boston Children's Hospital is located was renamed "Blackfan Street" in recognition of the countless contributions of a man who dedicated his life to forever change the landscape of pediatrics, and through his fidelity of purpose, had a significant impact on pediatric neurosurgery as well.

Acknowledgments The authors would like to thank the following individuals for providing invaluable assistance in gathering historical information in preparation of this manuscript:

1. Frederick H. Lovejoy, Jr., M.D., Associate Physician-in-Chief and Deputy Chairman, Boston Children's Hospital, The William Berenberg Distinguished Professor of Pediatrics at Harvard Medical School

2. Photographic records: Alina J. Morris, M.L.I.S., Hospital Archivist, Boston Children's Hospital, Boston, MA

3. Letters of correspondence: Marjorie Winslow Kehoe, Accessioning and Reference Archivist, The Alan Mason Chesney Medical Archives, Johns Hopkins Medical Institution, Baltimore, MD

\section{References}

1. Gamble J (1942) In Memoriam-Kenneth Danial Blackfan. J Pediatr 20

2. Gamble J, Powers GF, Wilson J, Rotch AG, Wolbach SB (April, 1942) Kenneth D. Blackfan. Harvard Medical Alumni Bulletin 16: Supplement

3. Diamond LK (November 17, 1986) Personal interview. Columbia University Oral History Research Office

4. Wilson JL (1955) Kenneth D. Blackfan; 1883-1941. J Pediatr 47: 261-267

5. Park E (1964) The history of the Harriet Lane Home. "The Child" symposium, Children's Medical \& Surgical Center, Johns Hopkins Hospital, 75th Anniversary Baltimore, Maryland

6. Fox WL (1984) Dandy of Johns Hopkins. Williams \& Wilkins

7. Dandy WE (1919) Experimental hydrocephalus. Ann Surg 70:129 142

8. Katz B (2012) Annual Report, Cincinnati Children's Hospital. Illuminating discoveries; bridging research, care and community. Cincinnati Children's Hospital Medical Center

9. Blackfan KD (1931) The Children's Hospital and The Infants' Hospital, Boston, Mass. Harvard Medical Alumni Bulletin

10. Blackfan KD (January 1, 1948) Atlas of the blood in children. The Commonwealth Fund

11. Cohen AR (2014) Boston children's hospital and the origin of pediatric neurosurgery. Childs Nerv Syst 30:1621-1624

12. Lohani S, Cohen AR (2013) Franc D. Ingraham and the genesis of pediatric neurosurgery. J Neurosurg Pediatr 11:727-733 